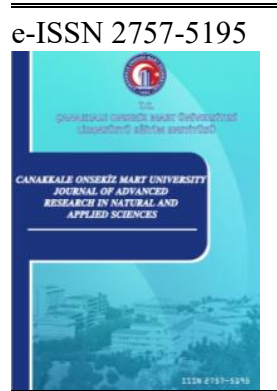

Çanakkale Onsekiz Mart University

Journal of Advanced Research in Natural and Applied Sciences

Open Access

\title{
Effect of Vitamin C on Cadmium Depending Growth and Vitamin C Contents of Citrobacter Freundii
}

\author{
Muhammad Salihu Ibrahim ${ }^{1}$, Meltem Çakmak ${ }^{2}$, Dursun Özer ${ }^{2}$, Fikret Karatas ${ }^{1 *}$, \\ Sinan Saydam ${ }^{1}$ \\ ${ }^{1}$ Department of Chemistry, Faculty of Science, Firat University, Elazig, Turkey \\ ${ }^{2}$ Department of Chemical Engineering, Faculty of Engineering, Firat University, Elazig, Turkey
}

\begin{abstract}
Article History
Received: $\quad 08.06 .2021$

Accepted: $\quad 31.08 .2021$

Published: $\quad 20.09 .2021$
\end{abstract}

Research Article

\begin{abstract}
Citrobacter freundii bacteria were grown in LB medium containing cadmium ion. In order to reduce adverse effect caused by cadmium, different concentrations of vitamin $\mathrm{C}$, were added to the growth medium. While the concentration of bacteria grown was determined by spectrophotometer, the amounts of water and fat-soluble vitamins were also determined by HPLC. The cadmium concentration varied from 0 (control), to 10, 20, 40, 60, 75, $100,125 \mathrm{ppm}$ in LB growth medium. The effect of cadmium has not been observed on the growth of bacteria, up to $40 \mathrm{ppm}$, on the other hand no significant microorganism growth was observed over $150 \mathrm{ppm}$ cadmium. Significant change of bacteria concentration was observed in the medium containing 75, 100 and $125 \mathrm{ppm} \mathrm{Cd}$. Microorganism concentrations decreased $18.8,40.5$ and 45.5 percent in the growth medium containing 75,100 and 125 ppm Cadmium respectively. With the addition of $75 \mathrm{ppm}$ vitamin $\mathrm{C}$ to the same growth medium, microorganism concentration was decreased about 2.0, 28.0 and 31.0 percent, respectively compared to the control. In addition, fat and water-soluble vitamins in bacteria grown in cadmium-containing medium was decreased in comparison to the control ( $\mathrm{p}<0.05)$. With the addition of 25,50 and $75 \mathrm{ppm}$ vitamin $\mathrm{C}$ to cadmium-containing medium, fat and water soluble vitamin concentrations were increased. As a result, it can be said that the negative effects of cadmium on bacterial growth and vitamin content can be reversed by the addition of vitamin $\mathrm{C}$ in to the growth medium of bacteria.
\end{abstract}

Keywords-Cadmium, Citrobacter freundii, $H P L C$, vitamin C, vitamins

\section{Introduction}

Bacteria is a microscopic single-cell species that prosper in a number of medium, such as soil, water, inside gut. Bacteria may be grouped on the basis of cell structure, cell metabolism or cell component variations like structure of DNA, fatty acids, pigments and antigens. Bacteria often give us a hand of support in various occasions such as conversion of milk to yogurt or helping with our digestion. As only bacteria and some archaea have the genes and enzymes required for synthesizing vitamin $\mathrm{B}_{12}$ also known as cobalamin and supplying it via the food chain almost all animal life depends on bacteria for survival (Fang et al. 2017). Bacteria have a remarkable ability to breakdown a number of organic compounds and have been used in the production and bioremediation of waste. Bacteria also used to remove oil spills to digest the hydrocarbons (Cohen, 2002). C. freundii is a member of the Enterobacteriaceae family which is gram-negative bacterium (O'Hara et al. 1997), that is a soil microorganism, may also be seen in other places such as food intestinal tracts and sanitation (Wang et al. 2000). Even though C. freundii is a bacterial pathogen, also plays a big part

\footnotetext{
1 (D) muhammadibrahim1247@gmail.com

2 (D) cakmak_meltem@hotmail.com

3 (iD) dozer@firat.edu.tr

4 (i) fkaratas@firat.edu.tr

5 (i) ssaydam@firat.edu.tr

${ }^{*}$ Corresponding Author
} 
in the environment's nitrogen cycle, which is responsible for environmental reduction of nitrate to nitrite (Puchenkova, 1996). Heavy metals are toxic to living things even at low concentrations (Banfalvi, 2011). Cadmium is a heavy metal that has a substantial environmental and functional effect (Paschal et al. 2000). In biological systems, cellular organs and components such as cell membranes, mitochondria, lysosomes, endoplasmic reticulum, nuclei, certain metabolic enzymes, detoxification and cell damage repair have been documented to be impaired by heavy metals. Metal ions interact with components in cells, including DNA and nuclear proteins, causing damage to DNA and then altering conformation (Beyersmann \& Hartwig, 2008). Cadmium induces cytotoxic effects in an in vitro experiment at concentrations 0.1 to $10 \mathrm{mM}$ and the free radical damage to DNA. Vitamins perform regulatory functions in the living system rather than being a part of compounds. In this respect, they are similar to hormones and play a catalyst role in metabolic events. Vitamins help the efficient use of nutrients in energy generation (Kennedy, 2016). Vitamin C is effective in the release of some hormones in case of stress and has a strong antioxidant effect (Devaki \& Raveendran, 2017). Bacteria are the microorganisms with the highest number and mass on earth. Bacteria are used in the synthesis of many drugs used in the health industry because they use cheap renewable resources to multiply, their ability to reproduce at a high rate, and they can be modified due to their simple structure. In addition, it provides a great advantage in terms of medical research, as they have many common features with other living things. For the stated reasons, $C$. freundii (NRRL B-2643) was preferred in the study. The aim of this study is to investigate the effect of cadmium together with the counter effect of vitamin $\mathrm{C}$ on the growth and vitamin contents of $C$. freundii.

\section{Materials and Methods}

\subsection{Material}

In this study, Citrobacter freundii (NRRL B-2643) grown in LB medium (10.0 g peptone, $5.0 \mathrm{~g}$ Yeast extract and $10.0 \mathrm{~g} \mathrm{NaCl}$ per liter) was used. $C$. freundii available in our laboratory was used. All chemicals used in the study are of analytical purity and were obtained from Sigma-Merck.

The following groups were studied;

1. Control: $C$. freundii was added to sterile LB medium.

2. Cadmium group: Different amounts of cadmium chloride were added to the control group.

3. Vitamin C group: Different amounts vitamin $\mathrm{C}$ solution was added to the cadmium group.

After inoculation, it was incubated at $37^{\circ} \mathrm{C}$ with $150 \mathrm{rpm}$, for 18 hours in an orbital shaker (Selecta Rotabit, Spain). At the end of the incubation period, the concentration of bacteria was determined by reading the absorbance at $600 \mathrm{~nm}$ with spectrophotometer (CHEBIOS s.r.l. Italy)

Then growth medium centrifuged at $8000 \mathrm{rpm}, 10{ }^{\circ} \mathrm{C}$ for 10 minutes, (Nüve $\mathrm{NF} 800 \mathrm{R}$ Türkiye) the precipitated cells were washed twice with distilled water, and centrifuged again and used in further processing.

\subsection{Determination of fat soluble vitamins}

$6.0 \mathrm{~mL}$ ethanol was added to the known of amount of bacteria and vortexed. Then, the bacteria solution was sonicated (Wise Clean, WUC-AO3H, $170 \mathrm{~W}$ ) in ice water bath, 10 times each for 30 seconds. After that it was centrifuged at $8000 \mathrm{rpm}$ for 10 minutes, then $1.0 \mathrm{~mL}$ of $\mathrm{n}$-hexane was added to each tube and centrifuged again for 6 minutes, the $n$-hexane phase was taken into the glass tube and this process was repeated twice. The hexane was removed under vacuum at $30^{\circ} \mathrm{C}$ and $1.0 \mathrm{~mL}$ of methanol was added to solve vitamins and transferred to HPLC vials for analysis. Methanol-acetonitrile-water (33:63:4 v/v) was used as mobile phase (ODS-2 column, $25 \mathrm{~cm}, 4.6 \mathrm{~mm}$ ID, $5 \mu \mathrm{m}$ ) (Miller et al. 1984; Ibrahim et al. 2017). 


\subsection{Determination of water soluble vitamins}

The known amount of microorganism taken and $3.0 \mathrm{~mL}$ of distilled water was added and vortexed. The mixture was sonicated 10 times in ice-water bath for 30 seconds each. Then, $1.0 \mathrm{~mL}$ of $0.5 \mathrm{M} \mathrm{HClO}_{4}$ added and vortexed, the mixture were centrifuged at $8000 \mathrm{rpm}$ for 10 minutes. The supernatant was taken into vials and analysed by HPLC. Analyses of water soluble vitamins determined according to (Amidžić et al. 2005 and Ibrahim et al. 2017) using Supelcosil LC-18-DB column (150 mm x $4.6 \mathrm{~mm}$ ID, $5 \mu \mathrm{m}$ ), methanol, $5 \mathrm{mM}$ heptanesulfonic acid sodium salt in $0.1 \%$ trimethylamine (25:75 v/v), $\mathrm{pH} 2.8$ as mobile phase.

\subsection{Statistical Analysis}

All measurements were triplicated and results were subjected to statistical analysis by SPSS 10.0 and significance was expressed as $\mathrm{p}<0.05$.

\section{Results and Discussion}

C. freundii was grown in the presence of 0 (Control), 10, 20, 40, 60, 75, 100 and 125 ppm cadmium in LB medium. It was observed that, $C$. freundii concentration was not effected significantly by the addition of cadmium up to $40 \mathrm{ppm}$ when compared to the control ( $>>0.05$ ). Addition of cadmium to the LB growth medium at 75, 100 and $125 \mathrm{ppm}$ reduced the concentration of $C$. freundii to about 18.8, 40.5 and 45.5 percent respectively to the control. No significant microorganism growth was observed in cadmium concentrations higher than $150 \mathrm{ppm}$ (Figure 1).

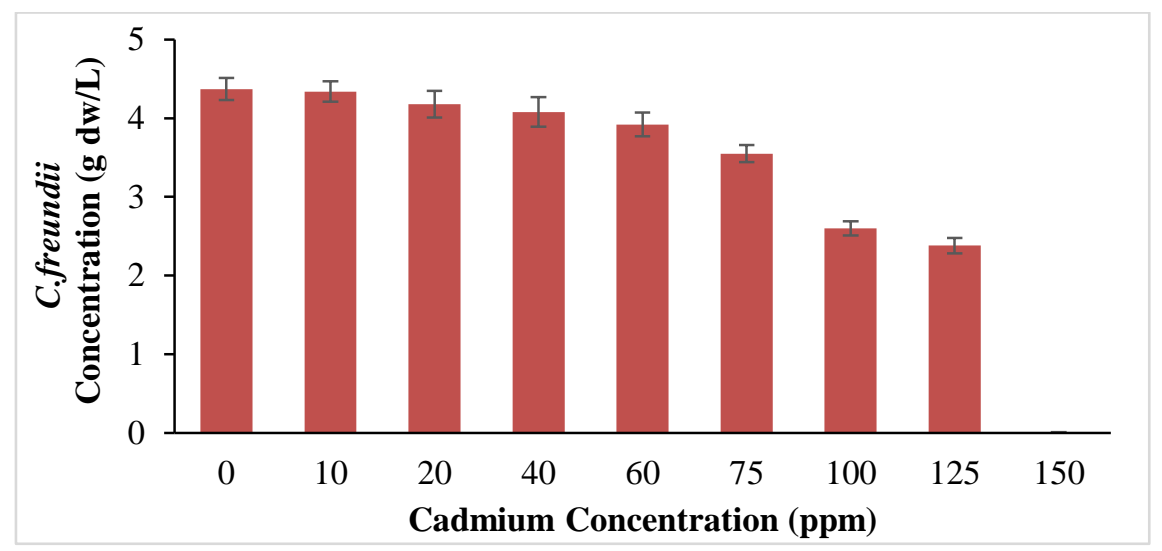

Figure 1. C. freundii concentrations at varying cadmium concentration

In the study conducted by Yiğit et al. (2013) it was reported that the growth rate of Lactobacillus brevis started to decrease more than $35 \mathrm{ppm}$ cadmium. It has been demonstrated that $100 \mathrm{ppm}$ cadmium concentration has a negative effect on the growth of B. mucilaginosus and A. niger microorganisms (Monballiu et al. 2015). The decrease in microorganism concentration may be due to the toxic effect of cadmium in the cell, which effects many metabolic activities including protein synthesis (Çınar, 2003).

To observe the counter effect of cadmium, various concentrations of vitamin $\mathrm{C}$ were added to the growth medium containing 75, 100 and $125 \mathrm{ppm}$ cadmium. Vitamin $\mathrm{C}$ has a role in tissue repair, protein formation, inactivation of toxic metals and protection of other vitamins (such as A and E), DNA from the harmful effects of oxidation (Hamza, 2017). In a study conducted by Sahiti et al. (2020), it was reported that vitamin C reduced the heavy metal accumulation in the tissues. Due to these properties of vitamin $\mathrm{C}$, various concentrations of vitamin $\mathrm{C}(25,50$ and $75 \mathrm{ppm})$ were added to the LB medium containing cadmium, in order to reduce the negative effect of cadmium. The concentration of microorganisms in the control $(4.37 \mathrm{~g} \mathrm{dw} / \mathrm{L})$ increased the to 4.64, 4.77 and $4.82 \mathrm{~g} \mathrm{dw} / \mathrm{L}$, with the addition of vitamin C, 25, 50 and $75 \mathrm{ppm}$ respectively.

It can be seen from the results that, the negative effect of cadmium decreased due to the increase in the vitamin $\mathrm{C}$ concentration added to the growth LB medium (Figure 2). As can be seen in Figure 2, $75 \mathrm{ppm}$ vitamin 
$\mathrm{C}$ added to the growth medium containing $100 \mathrm{ppm}$ cadmium, the bacteria concentration increased from 2.60 to $3.04 \mathrm{~g} \mathrm{dw} / \mathrm{L}$.

It has been reported that vitamin $\mathrm{C}$ is one of the effective factors in reducing the toxicity of cadmium (Fox et al., 1980). Vitamins, which have different biochemical functions, are organic compounds that are needed in small amounts for the proper functioning of metabolism. They are divided into two groups, fat and watersoluble. Retinoids are essential compounds for vision, reproduction, growth and strength of epithelial tissue. Carotenoids are powerful antioxidants against radical attacks as they pre-vent radicals formed during lipid peroxidation (Gutteridge \&Halliwell, 1988).

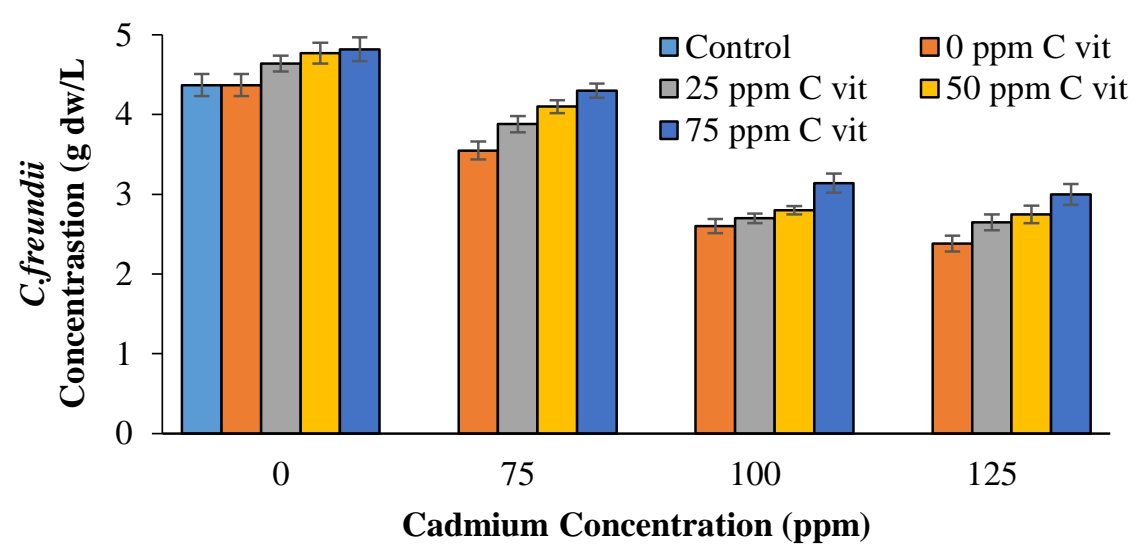

Figure 2. C. freundii concentrations at varying cadmium concentration with addition of vitamin C.

Vitamin $\mathrm{E}$ is an important in protecting unsaturated fatty acids in the cell membrane against the oxidation of free radicals. By saturating peroxides and hydroperoxides with hydrogen ions, it reduces the activity of peroxide radicals and inhibits the formation of auto-oxidation (Ognjanovic et al. 2003). The experimental results showed that a significant amount of vitamin $\mathrm{A}, \mathrm{E}$ and $\beta$-carotene were decrease in the microorganism depending on the cadmium concentration added to the growth medium ( $p<0.05$ ) (Figure 3,4,5). The loss of vitamin A, E and $\beta$-carotene in the $C$. fruendii $75 \mathrm{ppm}$ cadmium in the LB medium was found to be 48,45 and 41 percent, respectively, on the other hand, addition of $125 \mathrm{ppm}$ cadmium in to the LB growth medium, increased the vitamin loss to 71, 55 and 49 percent, respectively (Figure 3,4,5). Addition of vitamin $\mathrm{C}$ to the growth medium containing cadmium reduced the fat-soluble vitamin losses in the microorganism. The amount of reduction in vitamin losses was found to be depend on the added vitamin $\mathrm{C}$ concentration to the medium (Figure 3,4,5). When vitamin $\mathrm{A}, \mathrm{E}$ and $\beta$-carotene concentration compared in the microorganism with and without addition of $75 \mathrm{ppm}$ vitamin C to the LB medium containing 75 ppm cadmium, it was observed the increase of these compounds in the microorganism $0.30,0.96$ and $0.11 \mu \mathrm{g} / \mathrm{g} \mathrm{dw}$, respectively. 


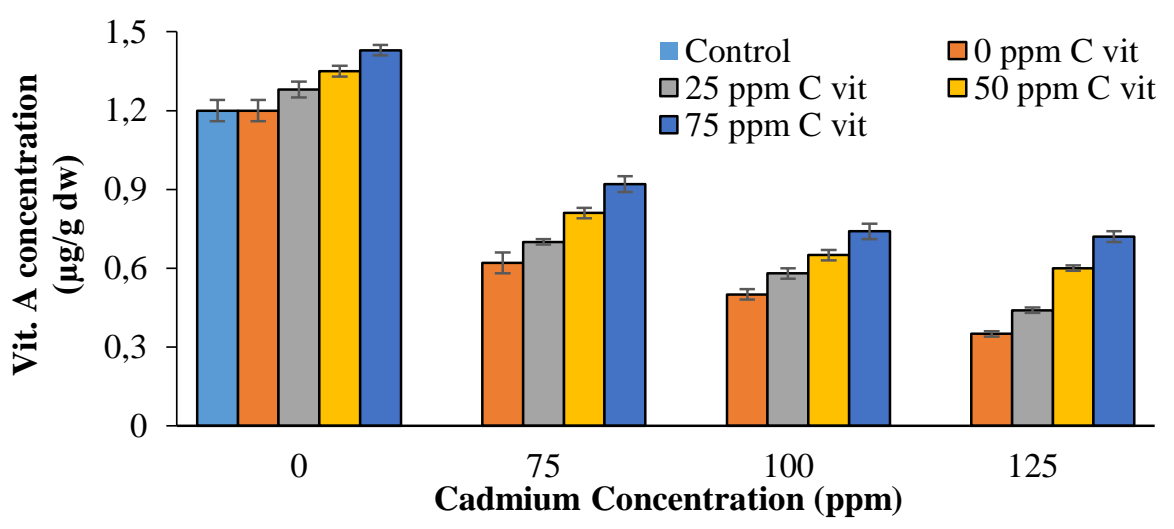

Figure 3. Effect of cadmium and vitamin $\mathrm{C}$ on the level of vitamin A in C. freundii.

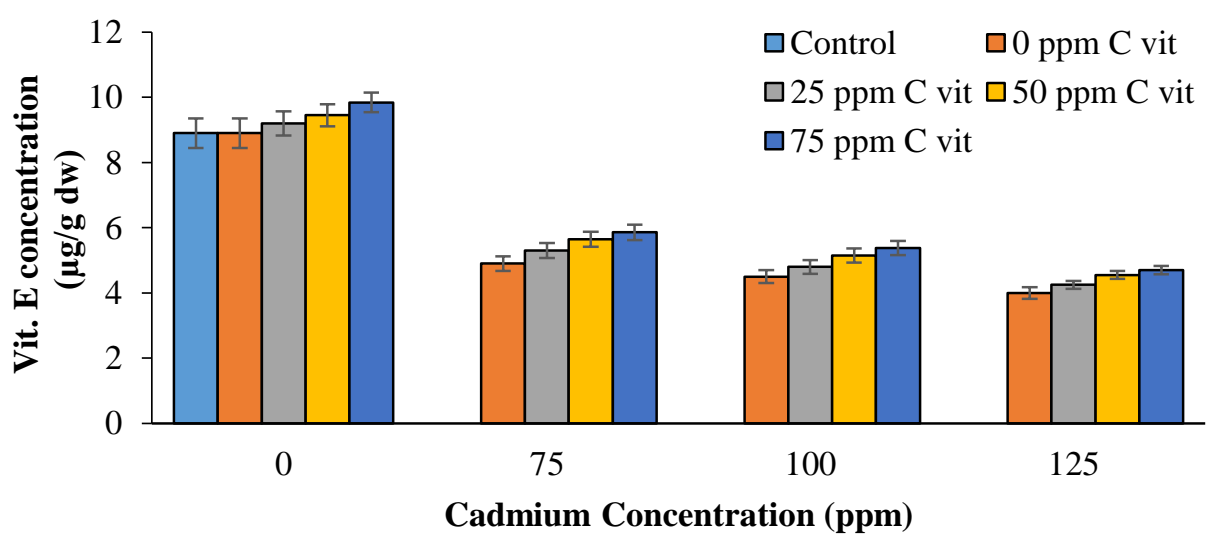

Figure 4. Effect of cadmium and vitamin $\mathrm{C}$ on the level of vitamin $\mathrm{E}$ in $C$. freundii.

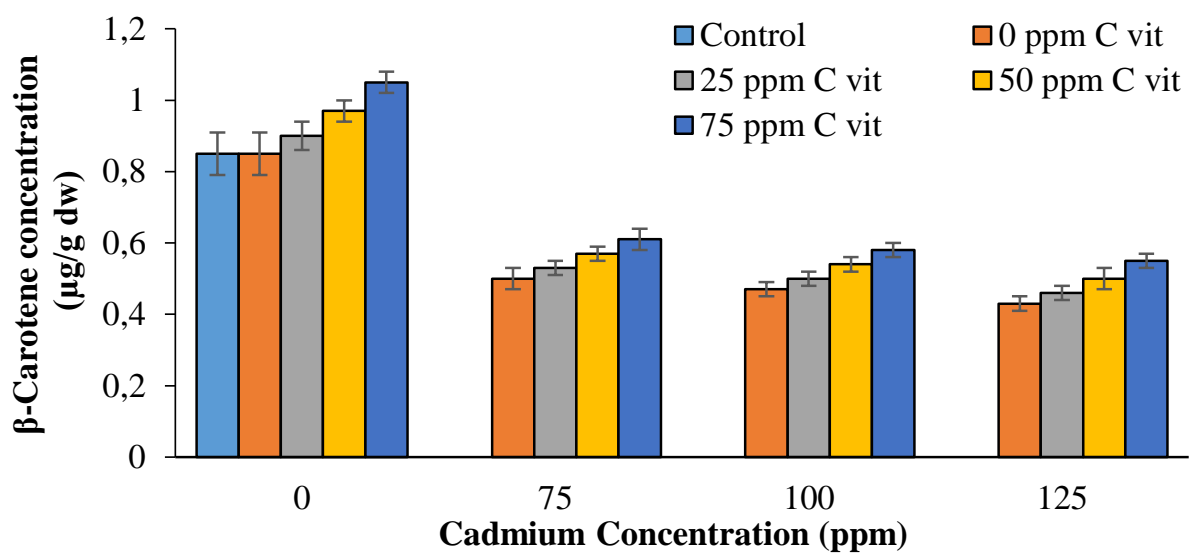

Figure 5. Effect of cadmium and vitamin $\mathrm{C}$ on the level of Beta-carotene in C. freundii.

Vitamins $\mathrm{B}_{1}, \mathrm{~B}_{2}, \mathrm{~B}_{3}, \mathrm{~B}_{5}$ and $\mathrm{B}_{6}$ play a key role in the energy metabolism of the cell. Vitamin $\mathrm{B}_{1}$ and $\mathrm{B}_{6}$ is an essential for a health of nervous system while vitamin $B_{3}$ regulates blood circulation. Vitamin $B_{6}$ and together with vitamin $B_{9}$, they play a role in the formation of red blood cells. Vitamin $B_{12}$ is an important in nucleic acid metabolism and myelin synthesis in addition to methyl transfer (Schellack, 2015; Young et al. 2019). 
A significant decrease in the amount of water-soluble vitamins in the microorganism was observed with the addition of cadmium to the growth medium. Increase of vitamin loss was proportional to the cadmium concentration in the nutrient medium ( $\mathrm{p}<0.05$ ) (Figure 6,7,8,9,10,11,12,13). Decrease in the level of $\mathrm{C}_{1} \mathrm{~B}_{1}, \mathrm{~B}_{2}$, $\mathrm{B}_{3}, \mathrm{~B}_{5}, \mathrm{~B}_{6}, \mathrm{~B}_{9}$ and $\mathrm{B}_{12}$ vitamins in the microorganisms, containing $75 \mathrm{ppm}$ cadmium in the growth medium, were $77,66,67,50,35,34,44$ and 45 percent respectively. In addition, $125 \mathrm{ppm}$ with cadmium in medium, further decreased the respective vitamin contents to $92,83,92,66,53,47,60$ and 63 percent, respectively. Vitamin $\mathrm{C}$ added to the medium containing cadmium decreased the water-soluble vitamins loss in the microorganism. The amount of decreased in water-soluble vitamin losses has been shown to depend on the vitamin $\mathrm{C}$ concentration added to the medium (Figure 6,7,8,9,10,11,12,13). With the addition of $75 \mathrm{ppm}$ vitamin $\mathrm{C}$ to the growth medium of bacteria containing 100 ppm cadmium, the amount of vitamins $\mathrm{C}_{1} \mathrm{~B}_{1}, \mathrm{~B}_{2}, \mathrm{~B}_{3}, \mathrm{~B}_{5}, \mathrm{~B}_{6}$, $\mathrm{B}_{9}$ and $\mathrm{B}_{12}$ in the microorganism, has increased about 5.5, 2.3, 2.0, 45, 36, 30, 0.8 and $0.32 \mathrm{ppm}$, respectively.

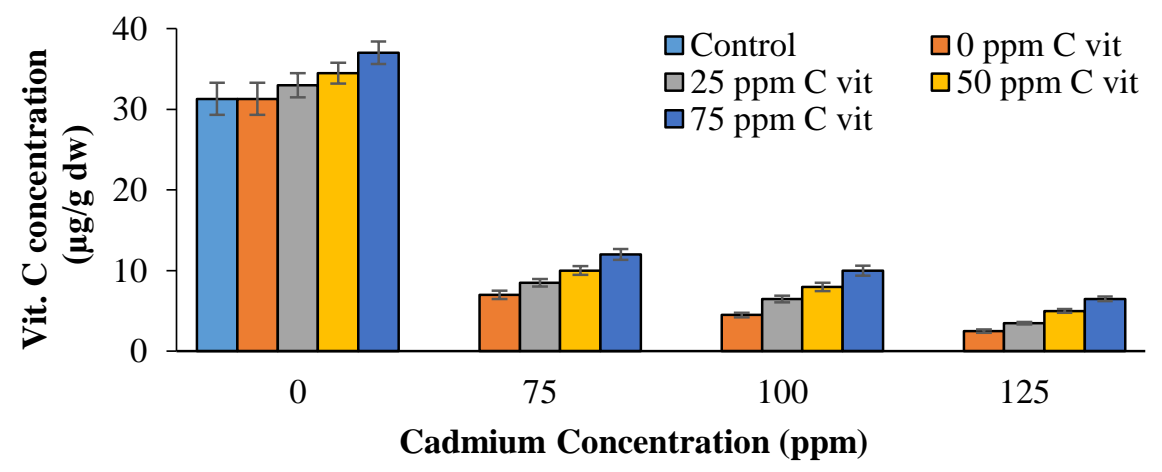

Figure 6. Effect of cadmium and vitamin $\mathrm{C}$ on the level of vitamin $\mathrm{C}$ in $C$. freundii

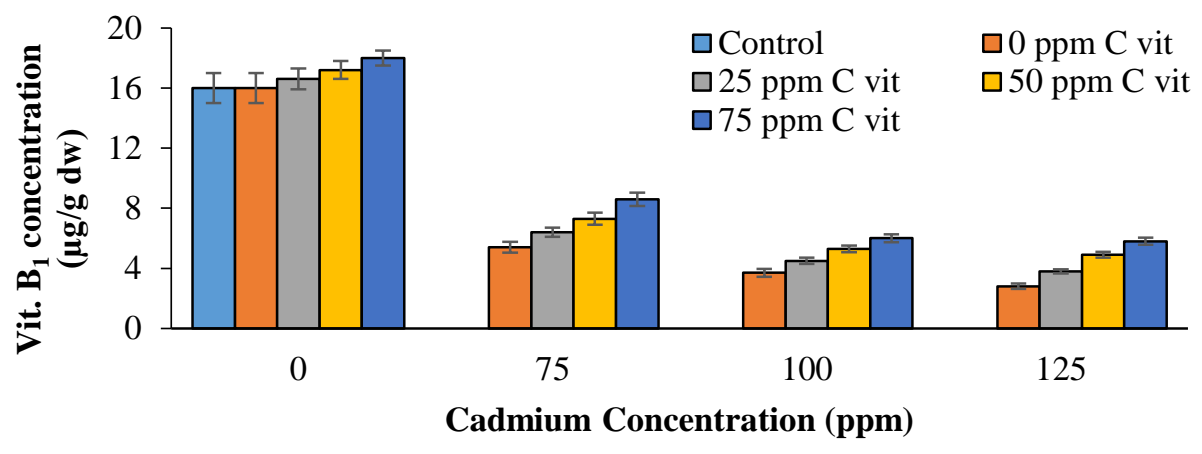

Figure 7. Effect of cadmium and vitamin $\mathrm{C}$ on the level of vitamin $\mathrm{B}_{1}$ in $C$. freundii. 


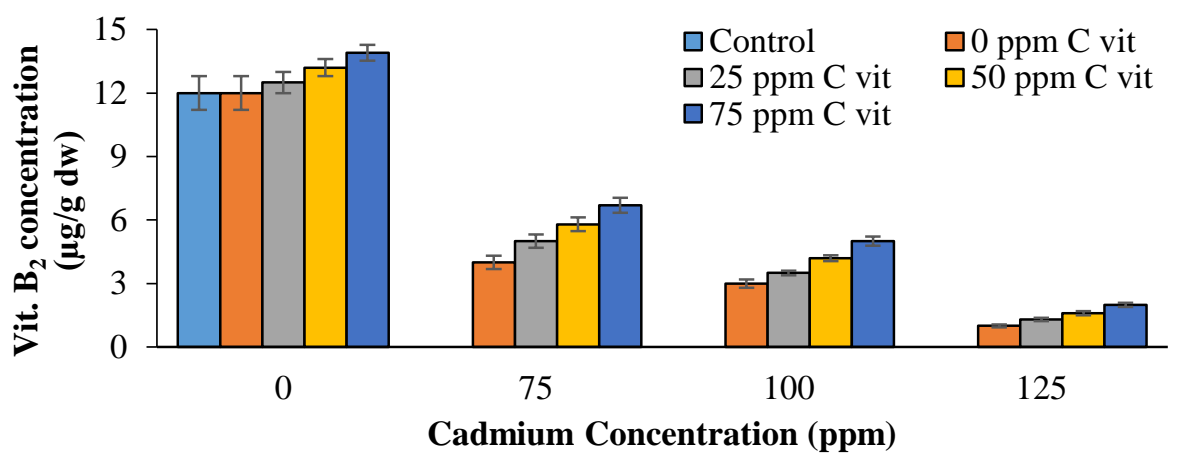

Figure 8. Effect of cadmium and vitamin $\mathrm{C}$ on the level of vitamin $\mathrm{B}_{2}$ in $C$. freundii.

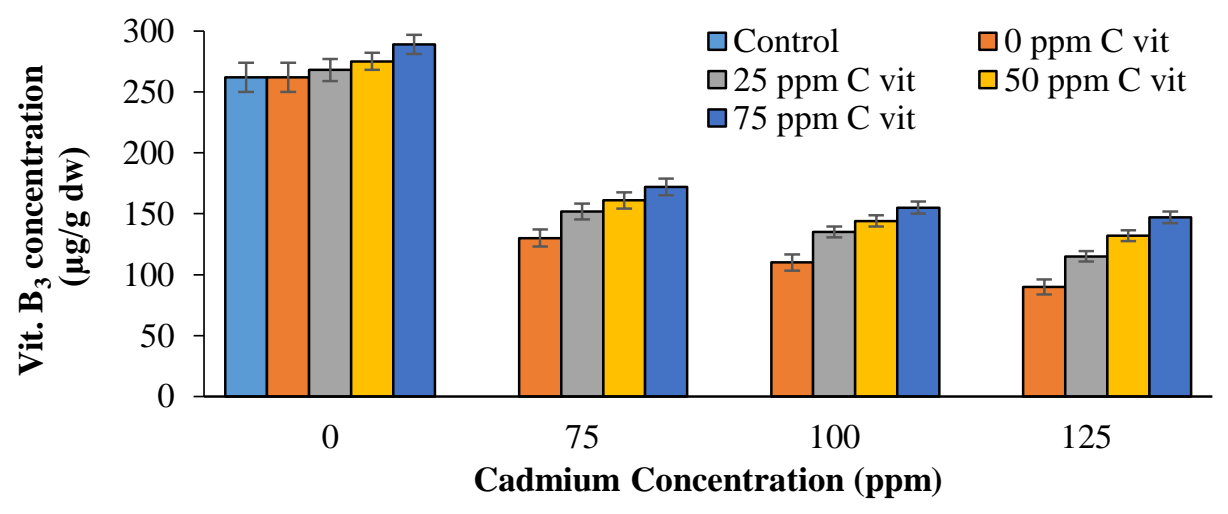

Figure 9. Effect of cadmium and vitamin $\mathrm{C}$ on the level of vitamin $\mathrm{B}_{3}$ in $C$. freundii.

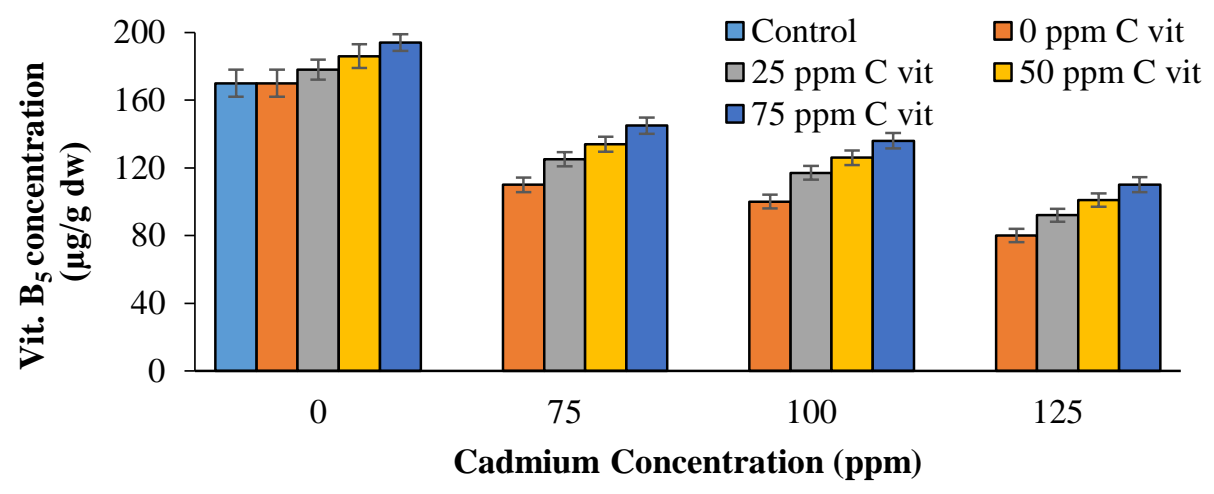

Figure 10. Effect of cadmium and vitamin $\mathrm{C}$ on the level of vitamin $\mathrm{B}_{5}$ in $C$. freundii. 


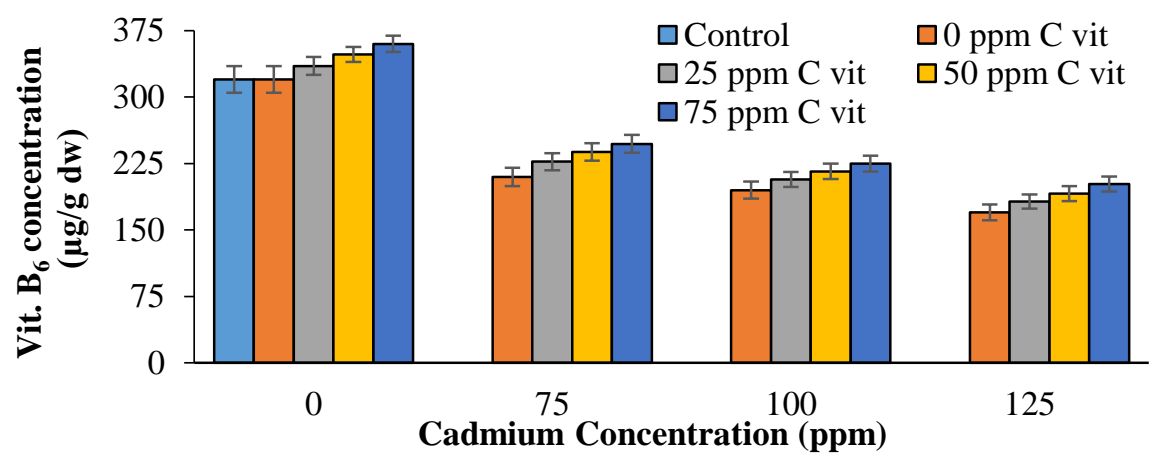

Figure 11. Effect of cadmium and vitamin $\mathrm{C}$ on the level of vitamin $\mathrm{B}_{6}$ in $C$. freundii.

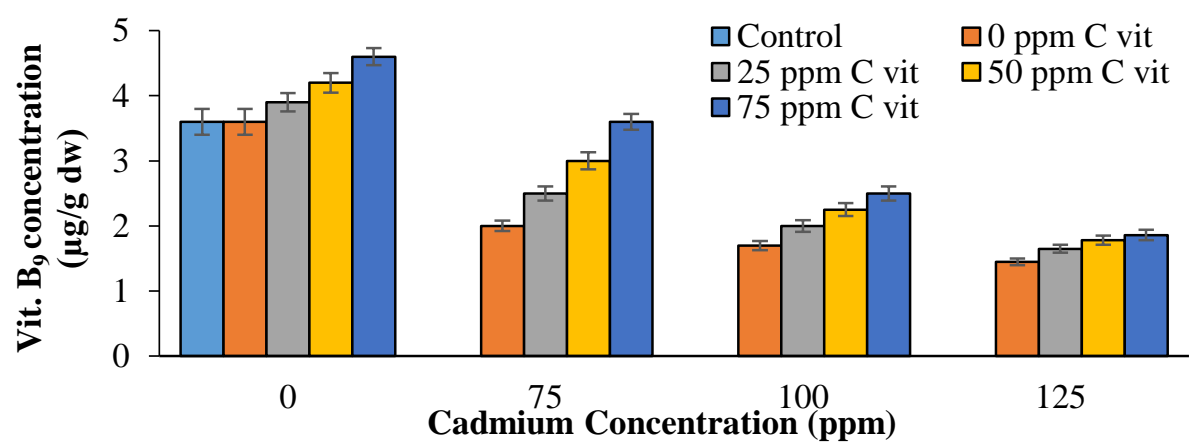

Figure 12. Effect of cadmium and vitamin $\mathrm{C}$ on the level of vitamin $\mathrm{B}_{9}$ in $C$. freundii,

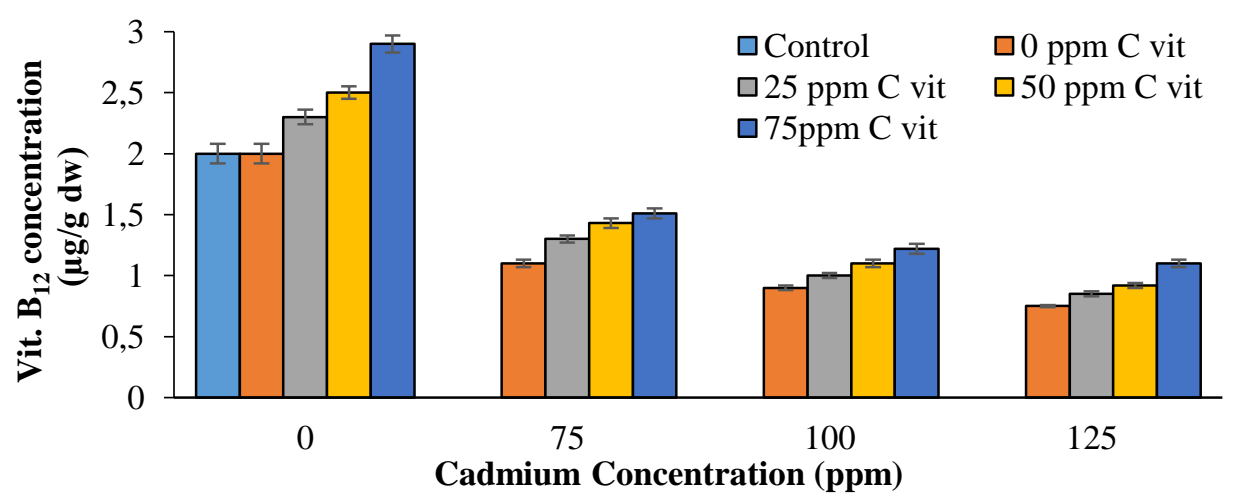

Figure 13. Effect of cadmium and vitamin $\mathrm{C}$ on the level of vitamin $\mathrm{B}_{12}$ in $C$. freundii,

Leigh (1983) found the amounts of vitamins $\mathrm{B}_{1}, \mathrm{~B}_{2}, \mathrm{~B}_{3}, \mathrm{~B}_{5}, \mathrm{~B}_{6}, \mathrm{~B}_{7}, \mathrm{~B}_{9}$ in B. subtilis bacteria as 5.8, 36, 1530, $210,2200,0.11$ and $1.10 \mu \mathrm{g} / \mathrm{g} \mathrm{dw}$, respectively. The reason for the decrease in the amount of vitamins with the addition of cadmium to the nutrient medium may be the result of the change in the membrane, DNA and thiol proteins of the microorganism, its interaction with antioxidant enzymes, inhibition in energy metabolism and oxidative stress (Casalino et al. 2002).

As a result, it can be said that vitamin $\mathrm{C}$ added to the nutrient medium containing cadmium increases both the concentration of microorganisms and the amount of fat and water-soluble vitamins by reducing the toxic and negative effects of cadmium on metabolism. 


\section{Conclusions}

It has been observed that, depending on the concentration of cadmium added to the LB medium for the production of the microorganism, the growth of the bacteria as well as the decrease in the content of fat and water soluble vitamins. The addition of vitamin $\mathrm{C}$, known for its antioxidant properties, to the nutrient medium containing cadmium reduced the negative effect of cadmium depending on the vitamin concentration.

\section{Acknowledgement}

Firat University was financially supported by the Scientific Research Projects Unit (FÜBAP) with the project number FF 18.15 .

\section{Author Contributions}

Muhammad Salihu Ibrahim: Performing the experiments.

Meltem Çakmak: Performing the experiments.

Dursun Özer: Designing the experiments, evaluating the results and writing.

Fikret Karatas: Designing the experiments, evaluating the results and writing.

Sinan Saydam: Designing and writing the manuscript.

\section{Conflicts of Interest}

The authors declare no conflict of interest.

\section{References}

Amidžić, R., Brborić, J., Čudina, O., \& Vladimirov, S. (2005). Rp-HPLC determination of vitamins, folic acid and B12 in multivitamin tablets. Journal of the Serbian Chemical Society, C 70, 1229-1235. DOI: http://doi.org/10.2298/JSC0510229A

Banfalvi, G. (2011). Cellular Effects of Heavy Metals. Netherlands, London, New York: Springer. ISBN 978-94-007-0428-2

Beyersmann, D., \& Hartwig, A. (2008). Carcinogenic metal compounds: recent insight into molecular and cellular mechanisms. Archives of toxicology, C 82, 493-51. https://doi.org/10.1007/s00204-008-0313y. $2 \mathrm{~h}$

Casalino, E, Calzaretti, G., Sblano, C., \& Landriscina, C. (2002). Molecular inhibitory mechanisms of antioxidant enzymes in rat liver and kidney by cadmium. Toxicology, 179: 37-50. https://doi.org/10.1016/s0300-483x(02)00245-7.

Cohen, Y. (2002). Bioremediation of oil by marine microbial mats. International Microbiology, C 5, 189193. DOI: https://doi.org/10.1007/s10123-002-0089-5.

Çınar, M. (2003). Kadmiyumun biyolojik sistemdeki etkileri. Veterinarium, 14(1), 79-84, https://dergipark.org.tr/tr/download/article-file/906611

Devaki, S. J., \& Raveendran, R. L. (2017). Vitamin C: Sources, Functions, Sensing and Analysis. INTECH http://dx.doi.org/10.5772/intechopen.70162

Fang, H., Kang, J., \& Zhang, D. (2017). Microbial production of vitamin B 12: a review and future perspectives. Microbial Cell Factories, C 16, 15. https://doi.org/10.1186/s12934-017-0631-y.

Fox, M. R. S., Richard, M. J., Jacobs, R. M., Jones, A. O. L., \& Fry, B. E. (1980). Effects of vitamin C and iron on cadmium metabolism. Annals of the New York Academy of Sciences, 355, 249-26. https://doi.org/10.1111/j.1749-6632.1980.tb21343.x

Gutteridge, J. M. C., \& Halliwell, B. (1988). The Deoxsiriboz Assay Both for Free Radical and for Site Specific Hydroxyl Radical Production. Biochemistry, 253(3), 932-933. 
https://doi.org/10.1042/bj2530932

Hamza, Amal H. (2017). Vitamin C: Sources, Functions, Sensing and Analysis. 10.5772/66058 (Chapter 1), https://doi.org/10.5772/intechopen.7016

Ibrahim, M., Ibrahim, Y., Mukhtar, Z., \& Karatas, F. (2017). Amount of vitamin A, vitamin E, vitamin C, malondialdehyde, glutathione, ghrelin, beta-carotene, lycopene in fruits of Hawthorn, Midland (Crataegus laevigata). Journal of Human Nutrition \& Food Science, 5, 1112-1117. ISSN: 2333-6706

Kennedy, D. O. (2016). B Vitamins and the Brain: Mechanisms, Dose and Efficacy-A Review. Nutrients 8(68), 1-29. https://doi.org/10.3390/nu8020068

Leigh, J. A. (1983). Levels of Water-Soluble Vitamins in Methanogenic and Non-Methanogenic Bacteria. Applied and Environmental Microbiology, 45 (3), 800-803. https://doi.org/10.1128/aem.45.3.800803.1983

Miller, K. W., Lorr, N. A., \& Yang, C. S. (1984). Simultaneous determination of plasma retinol, $\alpha$ tocopherol, lycopene, $\alpha$-carotene, and $\beta$-carotene by high-performance liquid chromatography. Analytical biochemistry, C 138, 340-345. https://doi.org/10.1016/0003-2697(84)90819-4

Monballiu, A., Cardon, N., Tri Nguyen, M., Cornelly, C., Meesschaert, B., \& Chiang, Y.W. (2015). Tolerance of Chemoorganotrophic Bioleaching Microorganisms to Heavy Metal and Alkaline Stresses. Bioinorganic Chemistry and Applications, (2015), 1-9. https://doi.org/10.1155/2015/861874.

Ognjanovic, B. J., Pavlovic, S. Z., Maletic, D., Zikic, R. V., Stajn, A. S., Radojicic, R. M., Saicic, Z. S., \& Petrovic, V. M. (2003). Protective influence of vitamin E on antioxidant defense system inthe blood of rats treated with cadmium. Physiological Research, 52, 563- 570. https://pubmed.ncbi.nlm.nih.gov/14535831

O'Hara, C. M., Westbrook, G. L., \& Miller, J. M. (1997). Evaluation of Vitek GNI+ and Becton Dickinson Microbiology Systems Crystal E/NF identification systems for identification of members of the family Enterobacteriaceae and other gram-negative, glucose-fermenting and non-glucose-fermenting bacilli. Journal of Clinical Microbiology, C 35, 3269-3273. https://doi.org/10.1128/jcm.35.12.32693273.1997.

Paschal, D., Burt, V., Caudill, S., Gunter, E. W., Pirkle, J. L., Sampson, E. J., Miller, D. T., \& Jackson, R. J. (2000). Exposure of the US population aged 6 years and older to cadmium: 1988-1994. Archives of environmental contamination and toxicology, C 38, 377-383. https://doi.org/10.1007/s002449910050

Puchenkova, S. (1996). Enterobacteria in areas of water along the Crimean Coast. Mikrobiolohichnyi Zhurnal (Kiev, Ukraine: 1993), C 58, 3-7. https://europepmc.org/article/med/8983520

Sahiti, H., Bislimi, K., Rexhepi, A., \& Dalo, E. (2020). Metal Accumulation and Effect of Vitamin C and E in Accumulated Heavy Metals in Different Tissues in Common Carp (Cyprinus carpio) Treated with Heavy Metals. Polish Journal of Environmental Studies 29(1), 799-805. https://doi.org/10.15244/pjoes/103354

Schellack, G. (2015) B-complex vitamin deficiency and supplementation. South African Pharmaceutical Journal, 82(4), 28-32. http://www.sapj.co.za/index.php/SAPJ/article/view/2003

Wang, J., Chang, S., Chen, Y., \& Luh, K. (2000). Comparison of antimicrobial susceptibility of Citrobacter freundii isolates in two different time periods. Journal of Microbiology, Immunology and Infection, 33, 258-262. https://pubmed.ncbi.nlm.nih.gov/11269372

Yiğit, A., Aktaş, N., \& Şahan, T. (2013). Lactobacillus Brevis Mikroorganizmasının Çoğalma Kinetiğinin Cevap Yüzeyi Yöntemi ile İncelenmesi. Yüzüncü Yıl Üniversitesi Fen Bilimleri Enstitüsü Dergisi/ Journal of The Institute of Natural \& Applied Sciences 18 :(1-2):25-32, https://dergipark.org.tr/tr/download/article-file/204634

Young, L. M., Pipingas, A.,White, D. J., Gauci, S., \& Scholey, A. (2019). A Systematic Review and MetaAnalysis of B Vitamin Supplementation on Depressive Symptoms, Anxiety, and Stress: Effects on Healthy and 'At-Risk' Individuals. Nutrients, 11(9), 2232. https://doi.org/10.3390/nu11092232 